\title{
POTENSI MINUMAN FUNGSIONAL BERBASIS SUSU DENGAN ISOLAT BIJI ATAU KECAMBAH KORO PEDANG DALAM PENCEGAHAN PENYAKIT KARDIOVASKULAR
}

\section{Potential of Milk-Based Drinks with Jack Bean Seed or Sprout Protein Isolates for Cardiovascular Disease Prevention}

\author{
Bayu Kanetro, Agus Slamet, Cahyo Budiyanto* \\ Program Studi Magister Ilmu Pangan- Fakultas Agroindustri - Universitas Mercu Buana Yogyakarta \\ Jl Wates Km 10 - Yogyakarta 55753 \\ Penulis Korespondensi, email : Cahyo.budiyanto75@outlook.com
}

Disubmit : 28 Maret $2021 \quad$ Direvisi : 8 Agustus $2021 \quad$ Diterima : 3 Desember 2021

\begin{abstract}
ABSTRAK
Susu sapi diketahui mengandung nutrisi yang tinggi namun demikian adanya kolesterol dan asam lemak jenuh menjadi faktor pemicu penyakit kardiovaskular yang menjadi pembatas bagi konsumen orang dewasa ataupun orang tua. Penambahan isolat protein biji atau kecambah koro pedang 3\% pada penelitian sebelumnya memberikan profil asam amino yang lebih baik terutama Glisin, Alanin, Serin, Arginin, dan Lisin yang berperan dalam pencegahan penyakit kardiovaskular. Tujuan penelitian ini adalah untuk mengetahui pengaruh penambahan isolat biji ataupun kecambah koro pedang 3\% terhadap kadar kolesterol dan profil asam lemak sebelum dan setelah in vitro dibandingkan dengan susu sapi tanpa penambahan. Adapun rancangan penelitian yang digunakan adalah rancangan acak lengkap yang terdiri dari susu sapi murni tanpa penambahan (K0), susu dengan isolat biji koro pedang 3\% (K1) dan susu dengan isolat kecambah koro pedang 3\% (K2). Hasil penelitian menunjukkan bahwa penambahan isolat biji atau kecambah koro pedang 3\% pada susu sapi menurunkan kadar kolesterol susu sapi dan berbeda signifikan dibandingkan susu tanpa penambahan. Profil asam lemak susu ditambah isolat kecambah ataupun biji koro pedang adalah lebih baik dibandingkan susu sapi tanpa penambahan yaitu kadar asam lemak jenuh lebih rendah namun sebaliknya asam lemak tak jenuh lebih tinggi. Penurunan kadar kolesterol dan profil asam lemak setelah pencernaan in vitro terbaik adalah pada susu isolat kecambah koro pedang $3 \%$. Oleh karenanya, pada penelitian ini dapat disimpulkan penambahan isolat protein biji atau kecambah koro pedang 3\% memiliki potensi sebagai minuman fungsional untuk pencegahan penyakit kardiovaskular.
\end{abstract}

Kata kunci: Asam Lemak; In vitro; Kolesterol

\begin{abstract}
Cow's milk is known containing high nutrition, however, the presence of cholesterol and saturated fatty acids is a trigger factor for cardiovascular disease that becomes a limitation for adult or the elderly. Milk plus 3\% jack bean seed or sprouts protein isolate in previous studies showing a better amino acid profile, especially Glycine, Alanine, Serine, Arginine, and Lysine which contribute to cardiovascular disease prevention. The purpose of this study was to determine the effect of $3 \%$ addition jack bean seed or sprouts protein isolate in cow's milk to cholesterol levels and fatty acid profile before and after in vitro compared to cow's milk without addition. The experimental design used was a completely randomized design consisting of pure cow's milk without addition (K0), milk plus 3\% jack bean seed isolate (K1) and milk plus 3\% jack bean sprouts isolate (K2). The results showed that milk plus 3\% jack bean seed or sprouts protein isolates reduced its cholesterol levels and significantly different from milk without addition. The fatty acid profile of milk plus jack bean seed or sprouts protein isolates is better than cow's milk without addition, with lower saturated fatty acid content but higher unsaturated fatty acid. The best
\end{abstract}


Jurnal Teknologi Pertanian Vol. 22 No. 3 [Desember 2021] 187-200

Potensi Minuman Fungsional Berbasis Susu dengan Isolat Biji dalam Pencegahan Penyakit Kardiovaskular [Kanetro dkk]

reduction in cholesterol levels and fatty acid profile after in vitro digestion was in milk plus $3 \%$ jack bean sprouts protein isolate. Therefore, in this study, it can be concluded that milk plus 3\% jack bean seed or sprouts protein isolate has a potential effect on the prevention of cardiovascular disease.

Keywords : Cholesterol; Fatty Acid; In vitro

\section{PENDAHULUAN}

Kesadaran konsumen akan arti pentingnya kesehatan saat ini semakin meningkat akibat semakin banyak jenis penyakit degeneratif yang muncul salah satunya adalah penyakit kardiovaskular (CVD-cardiovascular disease). Menurut Anand et al. (2015), sebaran data untuk asupan diet penyakit kardiovaskular terbanyak berasal dari negara-negara berpendapatan tinggi namun sebaliknya tingkat kematian akibat penyakit kardiovaskular sebanyak lebih dari $80 \%$ berasal dari negara berpendapatan rendah hingga sedang. Menurut data WHO (World Health Organization), penyakit kardiovaskular (CVD) merupakan penyebab utama dari morbiditas dan mortalitas serta sepertiga dari seluruh kematian di Indonesia (Amine et al., 2003). Data dari Institute of Health Metric Evaluation dalam tulisan Maharani et al. (2019) menunjukkan bahwa selama beberapa tahun terakhir angka kematian dini akibat penyakit jantung koroner (PJK) diperkirakan menjadi 3.299 dan 2.555 kehilangan setahun kehidupan per 100.000 kejadian.

Naghshi et al. (2020) dalam studi kohort prospektif pada 18.683 articles jurnal yang dipublikasi PubMed, Scopus, dan ISI Web of Science hingga Desember 2019, menyimpulkan bahwa asupan protein total yang lebih tinggi dapat menurunkan resiko semua penyebab kematian penyakit kardiovaskular terutama asupan protein nabati memberikan resiko paling rendah. Penggantian sumber makanan tinggi protein hewani dengan protein nabati sumber terkait dengan umur panjang. Studi kohort perspektif ini juga sejalan dengan penelitian yang dilakukan oleh Kim et al. (2019), yang menyimpulkan bahwa pola makan yang didominasi pangan nabati dan rendah pangan hewani memberikan resiko penyakit kardiovaskular dan kematian lebih rendah karena memberikan jantung yang lebih sehat.

Penelitian terdahulu oleh Kanetro et al. (2020) mengenai minuman fungsional susu sapi yang ditambah isolat biji dan kecambah koro pedang 3\% menunjukkan profil asam amino yang lebih baik dan tinggi daripada susu sapi tanpa penambahan terutama kandungan asam amino Glisin, Alanin, Serin, Arginin, dan Lisin. Kemampuan modulasi asam amino Glisin terhadap metabolisme trigliserida seluler yang selanjutnya dapat mencegah sekaligus menurunkan resiko penyakit kardiovaskular (Grajeda-Iglesias dan Aviram, 2018), radang, kanker, diabetes, dan obesitas (Razak et al., 2017), sedangkan Alanin dan Serin diketahui dapat menurunkan resiko sekaligus mencegah penyakit neurologi seperti susah tidur, aldzhemier, ataupun parkinson pada manusia (Chernoff et al., 2017; Le Douce et al., 2020). Menurut Bahadoran et al. (2016), kandungan asam amino L-Arginin pada protein nabati berperan dalam mengatur tekanan darah dan berpotensi menurunkan resiko penyakit jantung koroner. Manfaat yang sama dalam pencegahan penyakit kardiovaskular juga terjadi karena adanya potensi dari asam amino L-lysin selain berpotensi dalam pencegahan demensia alzhemier (Singh et al., 2011).

Menurut Artaud-Wild et al. (1993), susu dan lemak susu diketahui memberikan peningkatan mortalitas akibat penyakit jantung koroner akibat pengaruhnya pada trombosis dan aterosklerosis karena terkait kandungan total kolesterol dan asam lemak jenuh di dalamnya. Dalam studi lain, Steinmetz et al. (1994) yang mengamati perbedaan efek lipid darah panelis yang mengkonsumsi 2-3 gelas/hari $(236 \mathrm{ml} / 1.000 \mathrm{kkal})$ susu murni atau susu skim dalam diet terkontrol selama 6 minggu pada 8 panelis pria 
dewasa menunjukkan bahwa jika dibandingkan susu murni, diet susu skim secara signifikan $(\mathrm{P}<0,001)$ mengurangi total kolesterol dan kolesterol LDL, namun tidak ada perubahan signifikan pada salah satu lipid, lipoprotein, atau apolipoprotein lainnya. Penelitian terbaru oleh Vasilopoulou et al. (2020) menunjukkan bahwa konsumsi diet tinggi lemak dengan asam lemak jenuh rendah dan produk susu yang diperkaya asam lemak tak jenuh tunggal selama 12 minggu pada 54 panelis dewasa yang beresiko penyakit kardiovaskular memberikan hasil kadar kolesterol LDL puasa lebih baik daripada produk susu normal yang berarti berpotensi menurunkan resiko penyakit kardiovaskular.

Berdasarkan kondisi di atas dalam penelitian lanjutan ini dilakukan pengamatan terhadap profil asam lemak dan kolesterol sebelum dan sesudah pencernaan in vitro dari minuman fungsional susu sapi yang ditambah isolat biji ataupun kecambah koro pedang 3\%.

\section{METODE}

\section{Sampel Susu Sapi dan Sampel Kacang} Koro Pedang (Canavalia ensiformis)

Susu sapi yang sudah dipasteurisasi komersial merek Greenfield berusia 1 bulan digunakan dalam penelitian ini untuk mendapatkan keseragaman dan ketahanan sampel selama percobaan. Biji kacang koro pedang yang digunakan dalam penelitian berasal dari petani di wilayah Kulonprogo, Yogyakarta, Indonesia dengan spesifikasi berwarna putih dan diameter $\pm 13-14 \mathrm{~mm}$.

Penyiapan Sampel Isolat Protein Biji dan Kecambah Koro Pedang (Canavalia ensiformis)

Berdasarkan metode Kanetro dan Setyowati (2013) yang sedikit dimodifikasi, proses penyiapan isolat protein biji dan kecambah koro pedang diawali dengan tahap sortasi biji kacang koro pedang (Canavalia ensiformis) dilanjutkan dengan pencucian menggunakan air mengalir sampai bersih dan perendaman dengan air selama 24 jam pada rasio 1:3 (koro pedang: air). Proses selanjutnya adalah penirisan dan perkecambahan dalam ruangan bersuhu kamar dan kelembaban relative 100\% selama 0 (untuk biji) dan 72 jam (untuk kecambah). Pengeringan biji atau kecambah setelah 0-72 jam dilakukan untuk mengurangi kadar air di dalam bahan menggunakan pengering kabinet bersuhu $50-55{ }^{\circ} \mathrm{C}$ selama 12 jam. Setelah kering selanjutnya digiling menjadi tepung dan kemudian dilarutkan menggunakan aquades dengan rasio tepung dan aquadest 1:10. Campuran ini selanjutnya dipanaskan menggunakan magnetic stirrer dan pemanas bersuhu $40{ }^{\circ} \mathrm{C}$, setelah suhu tercapai dilakukan peningkatan $\mathrm{pH}$ hingga $\mathrm{pH} 9$ menggunakan larutan kalium hidroksida $(\mathrm{KOH}) \quad 10 \% \quad(\mathrm{~b} / \mathrm{v})$ dan kemudian diturunkan $\mathrm{pH}$ nya menuju $\mathrm{pH} 4$ menggunakan larutan asam sitrat $20 \%$. Selanjutnya disaring dengan kain saring tahu dan endapan yang diperoleh selanjutnya dikeringkan hingga menjadi bubuk isolat protein biji ataupun kecambah koro pedang.

Bubuk isolat protein biji ataupun kecambah koro pedang ini kemudian digunakan untuk ditambahkan ke dalam susu sapi sebesar 3\%. Pencampuran dan pelarutan dilakukan dengan menggunakan Blender berkecepatan $1.500 \mathrm{rpm}$ selama 5 menit. Sampel campuran ini selanjutnya dilakukan uji kolesterol dan profil asam lemak sebelum dan setelah proses pencernaan in vitro.

\section{Uji Gizi Secara In vitro Minuman Isolat Protein Kecambah Koro Pedang}

Sampel makanan cair $50 \mathrm{ml}$ ditempatkan ke dalam $50 \mathrm{ml}$ tabung dan percobaan pencernaan in vitro sesuai dengan rancangan percobaan di atas. Metode in vitro statis terdiri dari 3 tahap berbeda yaitu oral, lambung, dan usus sesuai metode Minekus et al. (2014):

1. Tahap oral : opsional bagi produk cair (Minekus et. al., 2014)

2. Tahap lambung: $10 \mathrm{ml}$ sampel cair dicampur dengan 7,5 ml larutan elektrolit stok SGF (Simulated Gastric Fluid-cairan asam lambung simulasi) setelahnya ditambahkan air hingga mencapai rasio akhir sampel cair dan SGF adalah 50:50 (v/v). Sebanyak 1,6 
$\mathrm{ml}$ larutan stock enzim pepsin 25.000 $\mathrm{U} / \mathrm{m}$ yang dibuat dengan mencampurkan pepsin 3.200-4.500 $\mathrm{U} / \mathrm{mg}$ dengan larutan elektrolit SGF. Selanjutnya dilakukan penambahan 5 $\mu \mathrm{laCl} 20,3 \mathrm{M}$ dan penambahan $0,2 \mathrm{ml}$ $\mathrm{HCl} 1 \mathrm{M}$ hingga $\mathrm{pH}$ 3,0 sesuai sistem pencernaan. Tahap akhir dilakukan penambahan air sebanyak 0,695 $\mu$ l. Rekomendasi waktu yang dibutuhkan untuk pencernaan di lambung adalah 2 jam pada suhu $37^{\circ} \mathrm{C}$.

3. Tahap usus: $20 \mathrm{ml}$ campuran hasil pencernaan lambung di atas dicampur dengan $11 \mathrm{ml}$ larutan stok elektrolit SIF (Simulated Intestinal Fluid - Cairan simulasi usus). Dilanjutkan dengan penambahan $5 \mathrm{ml}$ larutan pancreatin $800 \mathrm{U} / \mathrm{ml}$ yang dibuat dengan pencampuran larutan elektrolit SIF dan enzim pancreatin berdasarkan aktivitas tripsin. Dilakukan penambahan $2,5 \mathrm{ml}$ empedu segar $(160$ $\mathrm{mM}$ dalam empedu segar), $40 \mu \mathrm{l} \mathrm{CaCl} 2$ $0,3 \mathrm{M}, 0,15 \mathrm{ml} \mathrm{NaOH} 1 \mathrm{M}$ untuk mencapai $\mathrm{pH}$ 7,0 dan 1,31 $\mathrm{ml}$ air. Rekomendasi waktu untuk proses di tahap usus adalah sama 2 jam pada suhu $37^{\circ} \mathrm{C}$.

4. Sampel akhir dari tahap pencernaan ini apabila dilakukan tahap analisa lanjutan dapat dilakukan penambahan 0,5 M natrium bikarbonat sebelum dikering bekukan untuk mengawetkan dan menghentikan reaksinya.

\section{Profil Asam Lemak.}

Pengujian profil asam lemak sampel penelitian ini mengikuti gabungan metode AOAC (2005) dan Ratnayake et al. (2006), Tahap pertama analisa adalah membuat larutan standar dengan cara melarutkan larutan FAME-heksana ke dalam labu takar $100 \mathrm{ml}$ yang dihomogenkan. Setelah didapatkan titik tersebut selanjutnya sampel seberat 0,1-1 g dimasukkan dalam botol analisa $50 \mathrm{ml}$ dan dilanjutkan dengan penambahan $4 \mathrm{ml}$ isopropanol lalu divortex 1 menit dan dilanjutkan penambahan $6 \mathrm{ml}$ heksana dan dikocok dengan mechanical shaker $450 \mathrm{rpm}$ selama 5 menit. Setelah itu ditambahkan $3 \mathrm{ml}$ aquabides dan divorteks selama 1 menit. Sampel kemudian dilakukan sentrifugasi $4.500 \mathrm{rpm}$ selalu 3 menit. Setelah itu ambil lapisan atas dan dipindahkan ke dalam tabung ulir $10 \mathrm{ml}$, dilanjutkan dengan penguapan pelarut heksana dengan gas $\mathrm{N}_{2}$ pada suhu $50{ }^{\circ} \mathrm{C}$ agar terjadi reaksi metilasi. Ditambahkan $1,5 \mathrm{ml}$ larutan $\mathrm{KOH} \mathrm{0,5} \mathrm{M}$ dalam metanol ke dalam tabung ulir yang telah berisi ekstrak lemak. Selanjutnya divortex agar homogen.

Sampel homogen tersebut selanjutnya dipanaskan pada suhu $100{ }^{\circ} \mathrm{C}$ selama 20 menit. Kemudian didinginkan hingga suhu kamar dan dilanjutkan penambahan 1,5 mL BF3 20\% dalam metanol kemudian divorteks. Larutan kemudian dipanaskan kembali pada suhu $100{ }^{\circ} \mathrm{C}$ selama 20 menit. Kemudian larutan sampel didinginkan dan dikocok sampai larutan bersuhu $30 \quad{ }^{\circ} \mathrm{C}$, dilanjutkan penambahan $3 \mathrm{ml}$ larutan $\mathrm{NaCl}$ jenuh dan 2 $\mathrm{ml}$ heksana lalu divorteks selama 2 menit. Setelah terbentuk dua lapisan atas, diambil lapisan atas (fase organik) ke tube $2 \mathrm{ml}$ yang telah berisi $\mathrm{Na}_{2} \mathrm{SO}_{4}$ anhidrat dan dibiarkan selama 15 menit. Sampel kemudian didiamkan pada temperatur ruang. Setelah itu dimasukkan ke dalam botol analisa $2 \mathrm{ml}$ dan diinjeksikan ke dalam sistem GC (Gas Chromatography) FID dengan kondisi volume injeksi $1 \mu \mathrm{l}$, dengan suhu injeksi $240{ }^{\circ} \mathrm{C}$ menggunakan gas helium dan suhu oven $50-230{ }^{\circ} \mathrm{C}$ dengan lama analisa 24,67 menit.

\section{Uji Kolesterol}

Pengujian kolesterol sampel susu sapi yang ditambah isolat biji ataupun kecambah koro pedang menggunakan metode Gas Chromatography (GC) berdasarkan ASEAN Manual of Nutrient Analysis (Puwastien et al., 2011). Sampel susu dengan berat $0,5 \mathrm{~g}$ dimasukkan dalam tabung analisa $50 \mathrm{ml}$. Selanjutnya ditambahkan larutan $\mathrm{KOH} \mathrm{50 \%} \mathrm{dan} 4 \mathrm{ml}$ etanol. Setelah itu lakukan refluks dalam water bath $85-120^{\circ} \mathrm{C}$ selama \pm 60 menit dan diteruskan dengan pendinginan. Setelah dingin tambahkan $2,5 \mathrm{ml}$ aquabides dan 5 $\mathrm{ml}$ n-heksana lalu vortex selama 15 detik hingga larutan terpisah. Ambil lapisan organik kemudian masukkan dalam tabung reaksi $30 \mathrm{ml}$. Diulangi ekstraksi dengan 
heksana sebanyak 3 kali. Diuapkan pelarut hingga kering dengan gas $\mathrm{N}_{2}$ pada suhu 40 ${ }^{\circ} \mathrm{C}$. Sampel kering yang diperoleh selanjutnya direkonstitusi dengan menggunakan $3 \mathrm{ml}$ larutan dimetil formamida (DMF).

Larutan yang dihasilkan selanjutnya diambil $1 \mathrm{ml}$ untuk selanjutnya dimasukkan ke dalam tabung ulir $10 \mathrm{ml}$ yang sudah disililasi. Lakukan penambahan 0,2 $\mathrm{ml} \mathrm{HMDZ}$ dan 0,1 $\mathrm{ml}$ TMCS lalu vortex selama 1 menit dan didiamkan selama $15 \mathrm{ml}$. Selanjutnya lakukan penambahan $1 \mathrm{ml}$ larutan internal standar 5a-kolestan $100 \mathrm{mg} / \mathrm{l}$ dan divortex 15 detik dan dilanjutkan dengan penambahan $10 \mathrm{ml}$ aquabides dan dikocok kuat selama 1 menit. Ambil lapisan heptan yang merupakan lapisan paling atas yang selanjutnya diinjeksikan pada Gas Chromatography (GC) dengan tipe kolom kapiler HP-5MS UI menggunakan gas pembawa nitrogen pada kecepatan aliran konstan $2 \mathrm{ml} / \mathrm{min}$. Injeksi dilakukan menggunakan mode injeksi split 10:1 dengan volume injeksi $1 \mu \mathrm{l}$ pada suhu 305 ${ }^{\circ} \mathrm{C}$. Temperatur oven diatur dengan gradien $40^{\circ} \mathrm{C}$ sampai $315^{\circ} \mathrm{C}$. Detektor yang digunakan adalah detektor FID Parkin Elmer suhu $305^{\circ} \mathrm{C}$ dengan kecepatan aliran hydrogen $45 \mathrm{ml} /$ menit dan udara 450 $\mathrm{ml} /$ menit.

\section{HASIL DAN PEMBAHASAN}

\section{Profil Asam Lemak}

Pengujian profil asam lemak ditujukan untuk dapat mengetahui potensi isolat biji atau kecambah koro pedang sebagai pangan fungsional berbasis susu sapi dalam pencegahan penyakit kardiovaskular. Adapun profil asam lemak sampel susu sapi dan susu sapi yang ditambah isolat biji ataupun kecambah koro pedang 3\% disajikan pada Tabel 1.

Berdasarkan Tabel 1 tampak bahwa susu sapi yang dicampur isolat biji atau kecambah koro pedang memiliki kadar asam lemak jenuh lebih rendah dan berbeda nyata $(\mathrm{P}<0,05)$ dibandingkan dengan susu sapi tanpa penambahan. Selanjutnya susu yang ditambah isolat kecambah koro pedang menunjukkan kadar asam lemak jenuh yang paling rendah dibandingkan dengan seluruh sampel sehingga dapat dikatakan bahwa penambahan isolat kecambah koro pedang pada susu sapi memiliki potensi cukup besar sebagai minuman fungsional untuk pencegahan penyakit kardiovaskular. Pada review yang dilakukan oleh DiNicolantonio dan O'Keefe (2018), asam lemak jenuh (terutama asam laurat) telah terbukti meningkatkan kolesterol total dan kolesterol densitas rendah (kolesterol LDL) yang menyumbang terhadap resiko penyakit kardiovaskular. Engel et al. (2018) melakukan penelitian kadar lemak darah pada 18 orang dewasa sehat yang diberi diet $0,5 \mathrm{l} /$ hari susu full cream (tinggi lemak) dibandingkan dengan susu skim (rendah lemak) pada dosis yang sama, hasilnya menunjukkan bahwa diet susu full cream memberikan kadar kolesterol HDL darah lebih tinggi daripada susu skim.

Kadar asam lemak jenuh berupa asam laurat dari susu sapi yang ditambah isolat kecambah koro pedang menunjukkan nilai paling rendah dan berbeda nyata $(\mathrm{P}<0,05)$ dibandingkan dengan susu sapi ataupun susu sapi yang ditambah isolat biji koro pedang 3\%. Adapun kadar asam laurat dari rendah ke tinggi adalah sebagai berikut sampel susu yang ditambah isolat kecambah koro pedang adalah sebesar 0,927\% (bk) diikuti dengan susu yang ditambah isolat biji koro pedang sebesar 0,935\% (bk) dan susu sapi sebesar 1,010\% (bk). Kadar asam laurat yang rendah pada sampel susu dengan penambahan isolat kecambah koro pedang diduga terkait erat dengan senyawa antioksidan seperti fenol, flavonoid dan tokoferol yang terdapat dalam isolat kecambah kecambah koro pedang. Perkecambahan pada beberapa jenis kacang jenis korea selama 5-8 hari memberikan kadar polifenol dan flavonoid tertinggi dan berbeda nyata dibandingkan dalam bentuk bijinya (Adhikari et al., 2018). Lintschinger et al. (1997), dalam penelitiannya juga menemukan bahwa kecambah gandum merupakan sumber yang baik dari asam askorbat, riboflavin, kolin, tiamin, tokoferol dan asam pantotenat.

Kadar asam oleat (C18:1) sampel susu yang ditambah isolat kecambah koro pedang adalah terendah dibandingkan 
Jurnal Teknologi Pertanian Vol. 22 No. 3 [Desember 2021] 187-200

Potensi Minuman Fungsional Berbasis Susu dengan Isolat Biji dalam Pencegahan Penyakit Kardiovaskular [Kanetro dkk]

sampel lainnya dan berbeda nyata $(\mathrm{P}<0,05)$. Hal ini diduga karena rendahnya kadar asam oleat di dalam isolat kecambah dibandingkan isolat biji koro pedang. Hasil ini sejalan dengan penelitian Marton et al. (2010), kadar asam oleat dalam biji gandum turun dari $10,7 \%$ menjadi $7,8 \%$ dalam kecambah 3 hari, biji kacang lentil turun dari $14 \%$ ke 9,3\% setelah perkecambahan 3 hari dan biji bunga matahari turun dari $21,7 \%$ ke 21,0\% kecambah 3 hari, 20,9\% kecambah 5 hari.

Tabel 1. Profil asam lemak susu sapi tanpa penambahan isolat dan susu sapi yang ditambah isolat biji atau kecambah koro pedang $3 \%$.

\begin{tabular}{|c|c|c|c|c|}
\hline \multirow{3}{*}{ Parameter } & & \multicolumn{3}{|c|}{ Kadar asam lemak } \\
\hline & & & Susu Sapi + & $\begin{array}{c}\text { Susu Sapi + } \\
\text { Isolat }\end{array}$ \\
\hline & & & & \\
\hline & & & & \\
\hline Kaproat & C6:0 & $1,105 \pm 0,007 \mathrm{c}$ & $0,795 \pm 0,007 \mathrm{~b}$ & $0,430 \pm 0,000$ \\
\hline Kaprilat & C8:0 & $0,630 \pm 0,000^{c}$ & $0,490 \pm 0,014 \mathrm{~b}$ & $0,300 \pm 0,000$ \\
\hline Kaprat & $\mathrm{C} 10: 0$ & $1,085 \pm 0,007 \mathrm{c}$ & $0,890 \pm 0,014 \mathrm{~b}$ & $0,710 \pm 0,000$ \\
\hline Laurat & $\mathrm{C} 12: 0$ & $1,010 \pm 0,000 \mathrm{c}$ & $0,935 \pm 0,007 \mathrm{~b}$ & $0,927 \pm 0,079$ \\
\hline Miristat & C14:0 & $2,910 \pm 0,014 \mathrm{~b}$ & $2,830 \pm 0,028 \mathrm{~b}$ & $2,655 \pm 0,007$ \\
\hline Pentadekanoat & $\mathrm{C} 15: 0$ & $0,257 \pm 0,001 \mathrm{~b}$ & $0,250 \pm 0,003 \mathrm{~b}$ & $0,232 \pm 0,004$ \\
\hline Palmitat & C16:0 & $9,960 \pm 0,057 \mathrm{~b}$ & $9,975 \pm 0,078 \mathrm{~b}$ & $9,375 \pm 0,035$ \\
\hline Heptadekanoat & C17:0 & $0,043 \pm 0,000 \mathrm{a}$ & $0,046 \pm 0,001$ & $0,055 \pm 0,000$ \\
\hline Stearat & C18:0 & $2,655 \pm 0,021 \mathrm{~b}$ & $2,705 \pm 0,021^{c}$ & $2,520 \pm 0,014$ \\
\hline Arakidat & C20:0 & $0,035 \pm 0,000 \mathrm{~b}$ & $0,041 \pm 0,000^{c}$ & $0,034 \pm 0,000$ \\
\hline $\begin{array}{l}\text { Total Asam Lemak Jenuh } \\
\text { (SAFA - Saturated Fatty } \\
\text { Acid) }\end{array}$ & & $21,16 \pm 0,084^{c}$ & $20,04 \pm 0,042 \mathrm{~b}$ & $17,73 \pm 0,071$ \\
\hline Miristoleat & C14:1 & $0,315 \pm 0,007 \mathrm{~b}$ & $0,285 \pm 0,007 \mathrm{ab}$ & $0,270 \pm 0,000$ \\
\hline Pentadekanoat & $\mathrm{C} 15: 1$ & $0,058 \pm 0,000 \mathrm{~b}$ & $0,054 \pm 0,001{ }^{a}$ & $0,053 \pm 0,000$ \\
\hline Palmitoleat & C16:1 & $0,432 \pm 0,001 \mathrm{~b}$ & $0,438 \pm 0,007 \mathrm{~b}$ & $0,407 \pm 0,001$ \\
\hline Heptadekenoat & C17:1 & $0,043 \pm 0,000$ a & $0,046 \pm 0,001$ & $0,055 \pm 0,000$ \\
\hline Oleat & $\mathrm{C} 18: 1$ & $6,156 \pm 0,035 b$ & $5,857 \pm 0,040 \mathrm{a}$ & $5,833 \pm 0,028$ \\
\hline $\begin{array}{l}\text { Total Asam Lemak tak } \\
\text { Jenuh Tunggal (MUFA- } \\
\text { Mono Unsaturated Fatty } \\
\text { Acid) }\end{array}$ & & $7,002 \pm 0,029 c$ & $6,679 \pm 0,048^{b}$ & $6,622 \pm 0,028$ \\
\hline Linoleat & $\mathrm{C} 18: 2$ & $0,767 \pm 0,002^{\mathrm{ab}}$ & $0,810 \pm 0,028 \mathrm{~b}$ & $0,717 \pm 0,003$ \\
\hline Linolenat & $\mathrm{C} 18: 3$ & $0,064 \pm 0,000 \mathrm{a}$ & $0,089 \pm 0,000 \mathrm{~b}$ & $0,065 \pm 0,000$ \\
\hline Eikosatrienoat & C20:3 & $0,042 \pm 0,000 \mathrm{c}$ & $0,040 \pm 0,001 \mathrm{~b}$ & $0,038 \pm 0,000$ \\
\hline Arakidonat & C20:4 & $0,053 \pm 0,002 \mathrm{a}$ & $0,049 \pm 0,001 \mathrm{a}$ & $0,051 \pm 0,002$ \\
\hline $\begin{array}{l}\text { Total Asam Lemak tak } \\
\text { Jenuh Ganda (PUFA- Poly } \\
\text { Unsaturated Fatty Acid) }\end{array}$ & & $0,925 \pm 0,003 \mathrm{~b}$ & $0,988 \pm 0,030^{\mathrm{ab}}$ & $0,871 \pm 0,005$ \\
\hline $\begin{array}{l}\text { Jenuh (Unsaturated Fatty } \\
\text { Acid) }\end{array}$ & & $7,928 \pm 0,032 \mathrm{c}$ & $7,666 \pm 0,019 b$ & $7,492 \pm 0,033$ \\
\hline
\end{tabular}


Nilai terendah juga tampak pada total asam lemak tak jenuh rantai tunggal sampel susu yang ditambah isolat kecambah koro pedang dibandingkan dengan sampel susu dan susu yang ditambah isolat biji koro pedang. Kondisi ini dipengaruhi oleh kadar asam oleat (C18:1) yang berkontribusi besar pada total asam lemak tak jenuh sampel penelitian ini dan diketahui lebih rendah pada sampel susu dengan isolat kecambah koro pedang dibandingkan susu tanpa penambahan isolat ataupun dengan penambahan isolat biji koro pedang.

Pola kadar asam lemak tak jenuh rantai ganda (PUFA) tampak mengikuti pola yang sama dengan kadar asam lemak tak jenuh rantai tunggal (MUFA) yaitu susu dengan penambahan isolat kecambah koro pedang mengandung PUFA terendah dibandingkan dengan dua sampel yang lain. Namun demikian asam lemak tak jenuh rantai ganda (PUFA) susu yang ditambah isolat biji koro pedang lebih tinggi daripada susu sapi tanpa penambahan isolat. Hal ini diduga karena adanya aktivitas lipolitik dari enzim lipase seperti pada penelitian perkecambahan kacang hijau 72 jam oleh Abdel-Rahman et al. (2007) terhadap profil asam lemak kecambah yang dihasilkan dan menemukan kadar asam lemak esensial (linoleat dan linolenat) yang lebih rendah pada kecambah dibandingkan biji.

Rendahnya asam lemak tak jenuh rantai tunggal (MUFA) dan rantai ganda (PUFA) dalam sampel susu yang ditambah isolat kecambah koro pedang menyebabkan pula rendahnya total asam lemak tak jenuh dibandingkan dengan dua sampel lainnya yaitu susu sapi tanpa penambahan ataupun susu sapi dengan penambahan isolat biji koro pedang. Adapun kadar total asam lemak tak jenuh dari sampel susu sapi dengan penambahan isolat kecambah koro pedang, susu yang ditambah isolat biji koro pedang dan tanpa penambahan secara berturut-turut 7,49\% (bk), 7,67\% (bk) dan $7,93 \%$ (bk). Ketiga sampel tersebut secara statistik berbeda nyata pada taraf kepercayaan $95 \%$.

\section{Profil Asam Lemak Setelah In vitro}

Pencernaan in vitro yang direplikasi dalam penelitian ini hanya meliputi pencernaan di lambung dan usus sesuai metode yang terdapat dalam jurnal hasil penelitian Minekus et al. (2014) karena sampel berupa produk cair maka pencernaan di mulut bersifat opsional, selain itu parameter akhir yang diamati adalah profil asam lemak dan kolesterol maka pencernaan di mulut tidak berkontribusi di kedua parameter tersebut. Adapun hasil pengujian invitro disajikan pada Tabel 2.

Pada Tabel 2 disajikan profil asam lemak dan data persentase penurunan setelah pencernaan in vitro untuk melihat secara langsung pengaruh penambahan isolat biji atau kecambah koro pedang pada susu sapi selama pencernaan di lambung dan usus sehingga bisa saling dibandingkan efektivitasnya satu sama lain.

Kadar asam lemak jenuh susu yang ditambah isolat kecambah koro pedang menunjukkan nilai terendah sebesar 4,03 (\%bk) dan berbeda nyata $(\mathrm{P}<0,05)$ dibandingkan dengan dua perlakuan lainnya (susu tanpa penambahan dan susu yang ditambah isolat biji koro pedang). Selain itu jika dilihat dari penurunan kadar asam lemak jenuhnya perlakuan ini paling tinggi penurunannya yaitu $77,28 \%$.

Sejalan dengan asam lemak jenuh, penurunan kadar asam lemak tak jenuh tunggal (MUFA) pada sampel susu sapi yang ditambah isolat kecambah koro pedang 3\% menunjukkan penurunan yang cukup tinggi yaitu sebesar $82,96 \%$ atau dapat dikatakan bahwa kadar asam lemak tak jenuh tunggal yang tersisa adalah sebesar 1,129\% (bk). Penurunan ini diduga karena sebagian besar asam lemak tak jenuh tunggal ini berperan dalam proses penurunan kolesterol seperti halnya dalam penelitian Nouran et al. (2010), mengenai pemberian diet kacang tanah yang diketahui tinggi asam lemak tak jenuh tunggal (MUFA) pada penderita hiperkolesterolemia selama empat minggu, hasilnya menunjukkan penurunan kadar kolesterol total yang sangat signifikan sebesar 2,6\% (255,0 mg/dl menjadi 248,3 $\mathrm{mg} / \mathrm{dl}$ ). Penelitian Mensink et al. (1988), 
Jurnal Teknologi Pertanian Vol. 22 No. 3 [Desember 2021] 187-200

Potensi Minuman Fungsional Berbasis Susu dengan Isolat Biji dalam Pencegahan Penyakit Kardiovaskular [Kanetro dkk]

memberikan hasil bahwa penggantian lemak jenuh (SAFA) dengan asam lemak tak jenuh tunggal dalam diet cenderung

menurunkan tekanan darah baik pada panelis laki-laki ataupun perempuan serta pada pasien dengan hipertensi.

Tabel 2. Profil asam lemak susu sapi tanpa penambahan isolat dan susu sapi yang ditambah isolat biji atau kecambah koro pedang $3 \%$.

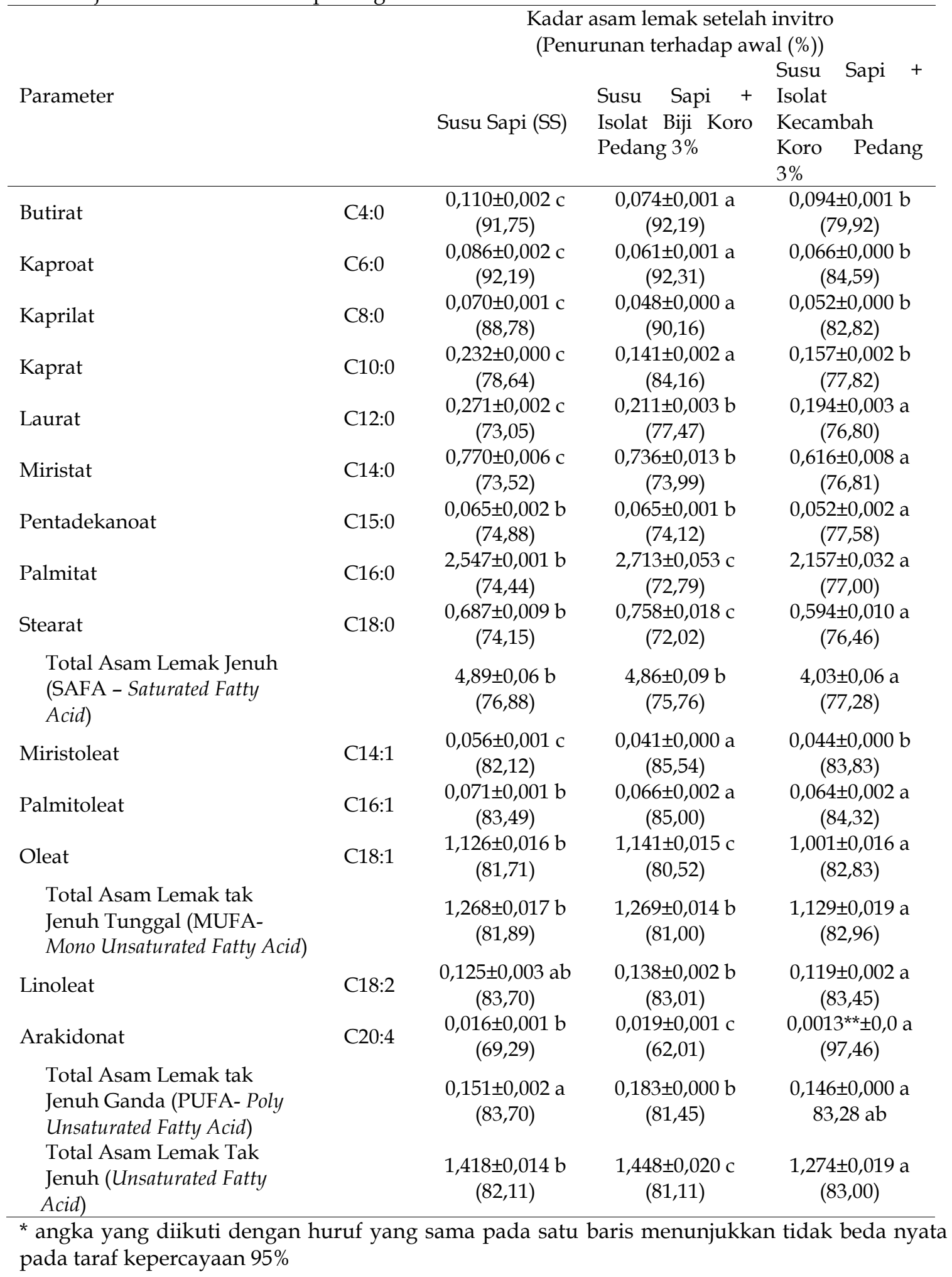


Salah satu asam lemak tak jenuh rantai tunggal yang berperan dalam penurunan kolesterol dalam plasma darah adalah asam oleat, terutama yang terdapat dalam minyak kacang kedelai dan minyak biji bunga matahari (Kris-Etherton, 1999). Kadar asam oleat susu yang ditambah isolat kecambah koro pedang 3\% menunjukkan penurunan tertinggi setelah pencernaan in vitro sebesar $82,63 \%$ turun dari 5,833\% (bk) menjadi 1,001\% (bk) dibandingkan dengan susu sapi yang mengalami penurunan hanya sebesar $81.71 \%$ (turun dari 6,156\% (bk) menjadi $1,126 \%$ (bk)) dan susu yang ditambah isolat biji koro pedang $3 \%$ penurunannya sebesar $80.52 \%$ (turun dari $5,857 \%$ (bk) menjadi $1,141 \%$ (bk)).

Penurunan yang sangat tajam terdapat pada asam lemak tak jenuh ganda yaitu asam arakidonat yang menunjukkan penurunan hingga $97,46 \%$ setelah pencernaan in vitro dengan kadar tidak terdeteksi atau di bawah batas minimal pengukuran yaitu $<0.00128 \%$ (bk) namun tidak terjadi pada sampel susu sapi (penurunan 69,29\%) ataupun susu sapi yang ditambah isolat biji koro pedang (penurunan $62.01 \%$ ). Asam arakidonat bersama dengan omega 6 terbukti sangat berpengaruh pada kadar kolesterol HDL dan LDL dalam plasma darah (Demetz et al., 2014).

Penurunan asam lemak tak jenuh rantai tunggal dan rantai ganda yang cukup tinggi pada sampel susu sapi yang ditambah isolat kecambah koro pedang dibandingkan sampel susu tanpa penambahan ataupun susu dengan penambahan isolat biji koro pedang menyebabkan penurunan yang signifikan pada asam lemak tak jenuhnya yaitu sebesar 83\% (turun dari 7,492\% (bk) menjadi $1,274 \%$ (bk) pada susu yang ditambah isolat kecambah koro pedang $3 \%$ ) $82.11 \%$ (turun dari $7,928 \%$ (bk) menjadi $1,418 \%$ (bk) pada susu sapi tanpa penambahan) dan penurunan $81.11 \%$ (turun dari 7,666\% (bk) menjadi 1,448\% (bk) pada susu sapi dengan penambahan isolat biji koro pedang $3 \%$ ).

Penurunan asam lemak tak jenuh yang cukup besar ini sejalan dengan penurunan kadar kolesterol setelah proses pencernaan in vitro yang berarti bahwa penambahan isolat kecambah koro pedang pada susu sapi dapat menjadi alternatif dalam pencegahan resiko penyakit kardiovaskular. Menurut Froyen dan Burns-Whitmore (2020), mekanisme asam lemak tidak jenuh dapat menurunkan kolesterol adalah dengan meningkatkan transkripsi gen alfa reseptor $x$ dari hati (liver $\mathrm{X}$ receptor alpha (LXRa)) melalui reseptor aktif peroksisom proliferator (peroxisome proliferator activated receptors (PPARs)) yang selanjutnya LXRa akan meningkatkan aktivitas enzim cholesterol $7 a-$ hydroxylase (CYP7) yang merubah kolesterol menjadi asam empedu, dengan kata lain asam lemak tak jenuh seperti asam lemak tak jenuh ganda (PUFA) berperan dalam katabolisme kolesterol.

\section{Kadar Kolesterol Awal dan Setelah Pencernaan In vitro}

Kadar kolesterol dari sampel susu sapi yang ditambah isolat biji ataupun kecambah koro pedang 3\% serta tanpa penambahan disajikan pada Gambar 1.

Berdasarkan Gambar 1, kadar kolesterol susu yang ditambah isolat biji ataupun kecambah koro pedang sebesar 3\% adalah lebih rendah dan berbeda nyata $(\mathrm{P}<0,05)$ dibandingkan susu sapi tanpa penambahan. Hal ini menunjukkan efektivitas penurunan kadar kolesterol dalam protein hewani karena diduga adanya senyawa antioksidan isoflavon yang terkandung dalam biji atau kecambah koro pedang. Menurut Yildiz (2006), isoflavon genistein menunjukkan aktivitas antioksidan tertinggi dan efek kolesterolemik yang diatas rata-rata. Penurunan kadar kolesterol total oleh isoflavon genistein biji kacang kedelai juga telah diteliti oleh Carolyn et al. (2019), hasilnya menunjukkan bahwa penurunan senyawa kolesterol dipengaruhi oleh protein, asam lemak tidak jenuh tunggal dan majemuk, antosianin dan isoflavon.

Penurunan kadar kolesterol setelah pencernaan invitro terbesar hingga 61,65\% ditunjukkan pada susu sapi yang ditambah isolat kecambah koro pedang 3\% yaitu penurunan kolesterol dari $94,14 \mathrm{mg} / 100 \mathrm{ml}$ menjadi $36,09 \mathrm{mg} / 100 \mathrm{ml}$ dibandingkan 
Jurnal Teknologi Pertanian Vol. 22 No. 3 [Desember 2021] 187-200

Potensi Minuman Fungsional Berbasis Susu dengan Isolat Biji dalam Pencegahan Penyakit Kardiovaskular [Kanetro dkk]

dengan sampel susu sapi tanpa penambahan isolat ataupun susu sapi yang ditambah isolat biji koro pedang. Kondisi ini diduga disebabkan kandungan senyawa aglikon yang lebih tinggi dalam kecambah. Menurut Yoshiaraa et al. (2018), senyawa aglikon dalam perkecambahan kacang kedelai tertinggi adalah pada perkecambahan 144 jam dibandingkan dalam bentuk biji (0 jam perkecambahan) dengan nilai sebesar 2,24 mg/100 g pada kecambah 0 jam dan 149,61 mg/100 g pada kecambah 144 jam. Namun demikian kadar senyawa aglikon akan berkurang kembali setelah 144 jam perkecambahan.

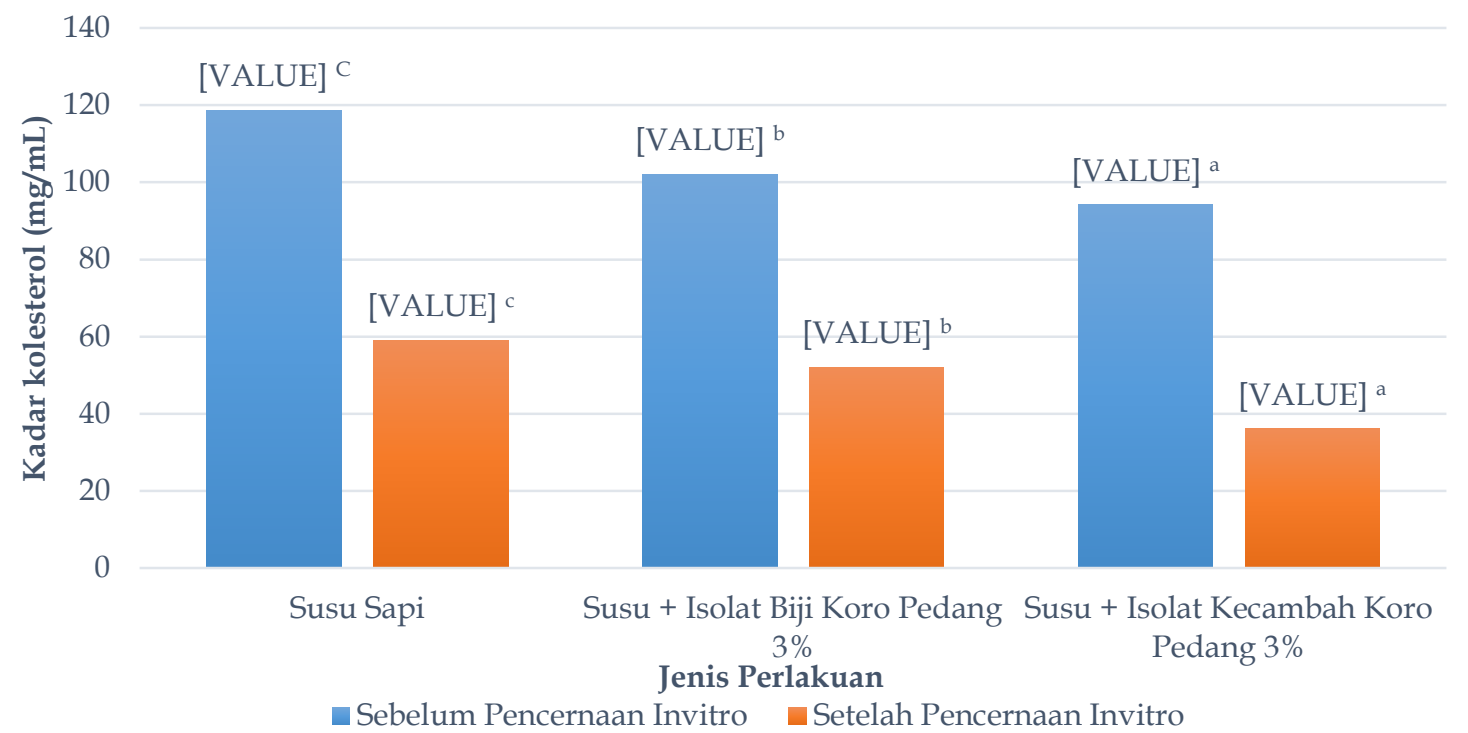

Gambar 1. Kadar kolesterol susu sapi dan susu sapi yang ditambah isolat biji atau kecambah koro pedang 3\% sebelum dan setelah pencernaan invitro (angka yang diikuti dengan huruf yang sama dalam grafik berwarna sama adalah tidak berbeda nyata pada taraf kepercayaan 95\%

Tingginya penurunan kadar kolesterol susu yang ditambah isolat kecambah koro pedang dibandingkan kedua sampel lainnya (susu tanpa penambahan isolat dan susu yang ditambah isolat biji koro pedang 3\%) berkaitan pula dengan tingginya kadar leusin di dalam sampel yaitu sebesar 2,80\% (bk). Kadar leusin pada dua sampel lainnya adalah 2,66\% (bk) pada susu sapi dan 2,56\% (bk) pada sampel susu yang ditambah isolat biji koro pedang 3\%. Studi klinis yang dilakukan oleh Coker et al. (2015) pada orang tua berusia 50 tahun ke atas dan diberi diet tambahan tinggi leusin dan fitosterol menunjukkan penurunan tertinggi signifikan kadar kolesterol total plasma darah juga trigliseridanya.

Keberadaan asam amino arginin yang lebih tinggi sebesar 0,925\% (bk) dalam sampel susu dengan penambahan isolat kecambah koro pedang 3\% dibandingkan dengan kedua sampel yaitu susu sapi tanpa penambahan (arginin:0,850\% (bk)) dan susu yang ditambahkan isolat biji koro pedang 3\% (arginin:0,825\% (bk)) diduga berkontribusi terhadap tingginya penurunan kadar kolesterol setelah pencernaan in vitro. Hal ini sejalan denagn penelitian yang dilakukan oleh Børsheim et al. (2012) mengenai pemberian diet tambahan berupa $11 \mathrm{~g}$ asam amino esensial dan arginin sebanyak dua kali sehari pada 12 pasang orang tua berumur 60-70 tahun yang toleran terhadap glukosa selama 16 minggu menunjukkan penurunan trigliserida hati dan plasma dan penurunan sensitivitas insulin yang berefek pula pada turunnya total kolesterol dan kolesterol densitas sangat rendah (VLDL) plasma darah. 
Selain asam amino leusin dan arginin, asam amino glisin, isoleusin, dan lisin juga berperan dalam mempengaruhi tingginya penurunan kadar kolesterol total dalam sampel susu sapi yang ditambah isolat kecambah koro pedang $3 \%$. Kandungan asam amino Glisin, Isoleusin dan Lisin dari sampel susu sapi yang ditambah isolat kecambah koro pedang 3\% adalah sebesar $0,673 \%$ (bk), 1,455\% (bk) dan $2.30 \%$ (bk).

Ketiga asam amino yang terkandung dalam sampel susu dengan penambahan isolat kecambah koro pedang 3\% lebih tinggi dari dua sampel lainnya (susu tanpa menambahan dan susu yang ditambah isolat biji koro pedang 3\%). Penelitian pada tikus tinggi kolesterol yang diberi pakan diet taurin dan diet glisin oleh Park et al. (1999), menunjukkan penurunan $40 \%$ total kolesterol pada diet taurin dan $27 \%$ pada diet glisin. O'rielly et al. (2020), meneliti tikus yang diberi pakan diet lemak tinggi dan memberikan pengaruh nyata pada total kolesterol meskipun tidak berefek pada metabolit lipida plasma.

Berdasarkan kontribusi asam-asam amino yang terdapat dalam susu sapi yang ditambah isolat kecambah koro pedang 3\% maka penurunan kadar kolesterol yang tinggi diduga berpotensi sebagai minuman fungsional berbasis susu yang dapat menurunkan resiko penyakit kardiovaskular. Ma dan Shieh (2006) menyampaikan bahwa kolesterol dan asam lemak jenuh memegang peranan penting pada kesehatan jantung manusia dan tingginya kadar kolesterol dapat menyebabkan penyakit kardiovaskular seperti serangan jantung dan stroke melalui proses pembentukan plak (deposit keras) pada arteri dari berkurangnya fleksibilitas arteri hingga penyumbatan aliran darah. Penelitian yang dilakukan oleh Ma et al. (2014) pada 90 orang panelis yang diberi diet $24 \mathrm{~g}$ isolat protein kedelai ataupun protein susu dengan kombinasi rasio lysine dan arginine memberikan pengaruh yang nyata pada total kolesterol dan kolesterol LDL.

\section{SIMPULAN}

Profil asam lemak susu yang ditambah isolat biji atau kecambah koro pedang 3\% menunjukkan nilai yang lebih baik (kadar asam lemak jenuh lebih rendah namun sebaliknya asam lemak tak jenuh yang lebih tinggi) dan berbeda nyata $(\mathrm{P}<0,05)$. Profil asam lemak setelah pencernaan in vitro juga menunjukkan penurunan kadar asam lemak jenuh yang lebih tinggi dibandingkan susu tanpa penambahan.

Kadar kolesterol sebelum dan sesudah pencernaan in vitro menunjukkan perlakuan penambahan isolat biji atau kecambah koro pedang 3\% pada susu sapi memberikan kadar kolesterol yang lebih rendah namun penurunan yang lebih tinggi dan berbeda nyata dibandingkan susu tanpa penambahan isolat. Oleh karena itu, penambahan isolat biji atau kecambah koro pedang diduga dapat berpotensi dalam pencegahan penyakit kardiovaskular.

\section{DAFTAR PUSTAKA}

Abdel-Rahman, E, -A., El-Fishawy, F, -A., ElGeddawy, M, -A., Kurz, -T., El-Rify, M, N., 2007. The changes in the lipid composition of mung bean seeds as affected by processing methods. International Journal of Food Engineering. 3(5), 1-10. https://doi.org/10.2202/15563758.1186

Adhikari, -B., Dhungana, S, -K., Ali, M, -W., Adhikari, -A., Kim, I, -D., Shin, D, -H., 2018. Resveratrol, total phenolic and flavonoid contents, and antioxidant potential of seeds and sprouts of Korean peanuts. Food Science and Biotechnology. 27(5), 1275-1284. https://doi.org/10.1007/s10068-018-0364-7

Amine, E, -K., Baba, N, -H., Belhadj, -M., Deurenberg-Yap, -M., Djazayery, -A., Forrestre, -T., Galuska, D, -A., Herman, -S., James, W, P, -T., M'Buyamba Kabangu, J, -R., Katan, M, -B., Key, T, J., Kumanyika, -S., Mann, -J., Moynihan, P, -J., Musaiger, A, -O., Olwit, G, -W., Petkeviciene, -J., Prentice, -A., Yach, -D., 2003. Diet, nutrition and the prevention of chronic diseases. World Health 
Jurnal Teknologi Pertanian Vol. 22 No. 3 [Desember 2021] 187-200

Potensi Minuman Fungsional Berbasis Susu dengan Isolat Biji dalam Pencegahan Penyakit Kardiovaskular [Kanetro dkk]

Organization - Technical Report Series, 916. https://doi.org/10.1093/ajcn/60.4.644a

Anand, S, -S., Hawkes, -S., Souza, R, -J., Mente, -A., Dehghan, -M., Nugent, -R., Zulyniak, M, -A., Weis, -T., 2015. Food consumption and its impact on cardiovascular disease: Importance of solutions focused on the globalized food system. A Report from the workshop convened by the world heart federation. Journal of the American College of Cardiology. 66(14), 1590-1614. https://doi.org/10.1016/j.jacc.2015.07.0 50

AOAC, 2005. Official Method of Analysis. 18th Edition. AOAC Press, Maryland, USA

Artaud-Wild, S, -M., Connor, S, -L., Sexton, G., Connor, W, -E., 1993. Differences in coronary mortality can be explained by differences in cholesterol and saturated fat intakes in 40 countries but not in France and Finland: A paradox. Circulation. 88(6), 2771-2779. https://doi.org/10.1161/01.CIR.88.6.2771

Bahadoran, -Z., Mirmiran, -P., Tahmasebinejad, -Z., Azizi, -F., 2016. Dietary L-arginine intake and the incidence of coronary heart disease: Tehran lipid and glucose study. Nutrition and Metabolism. 13(1), 1-9. https:// doi.org/10.1186/s12986-0160084-z

Børsheim, -E., Bui, Q, U, -T., Tissier, -S., Cree, M, -G., Rønsen, -O., Morio, -B., Fernando, A, -A., Kobayashi, -H., Newcomer, B, -R., Wolfe, R, -R., 2009. Amino acid supplementation decreases plasma and liver triglycerides in elderly. Nutrition. 25(3), 281-288.

Carolyn, -A., Farishal, -A., Berawi, -K., 2019. Potensi Pemberian isoflavon kedelai terhadap kadar kolesterol total dan LDL pada penderita obesitas. MEDULA. 9(1), 102-106

Chernoff, -N., Hill, D, -J., Diggs, D, -L., Faison, B, -D., Francis, B, -M., Lang, J, R., Larue, M, -M., Le, T, -T., Loftin, K, A., Lugo, J, -N., Schmid, J, -E., Winnik, W, -M., 2017. A critical review of the postulated role of the non-essential amino acid, $\beta$-N-methylamino-Lalanine, in neurodegenerative disease in humans. Journal of Toxicology and
Environmental Health - Part B: Critical

Reviews. 20(4), 183-229.

https://doi.org/10.1080/10937404.2017 .1297592

Coker, R, -H., Deutz, N, -E., Schutzler, -S., Beggs, -M., Miller, -S., Wolfe, R, -R., Wei, -J., 2015. Nutritional Supplementation with Essential Amino Acids and Phytosterols May Reduce Risk for Metabolic Syndrome and Cardiovascular Disease in Overweight Individuals with Mild Hyperlipidemia. Journal of Endocrinology, Diabetes and Obesity. 3(2), 1-15.

Demetz, -E., Schroll, -A., Auer, -K., Heim, C., Patsch, J, -R., Eller, -P., Theurl, -M., Theurl, -I., Theurl, -M., Seifert, -M., Lener, -D., Stanzl, -U., Haschka, -D., Asshoff, -M., Dichtl, -S., Nairz, -M., Huber, -E., Stadlinger, -M., Moschen, A, -R., Tancevski, -I., 2014. The arachidonic acid metabolome serves as a conserved regulator of cholesterol metabolism. Cell Metabolism. 20(5), 787-798. https://doi.org/10.1016/j.cmet.2014.09.004

DiNicolantonio, J, -J., O'Keefe, J, -H., 2018. Effects of dietary fats on blood lipids: A review of direct comparison trials. Open Heart. 5(2), 1-5. https://doi.org/10.1136/openhrt-2018000871

Engel, -S., Elhauge, -M., Tholstrup, -T., 2018. Effect of whole milk compared with skimmed milk on fasting blood lipids in healthy adults: A 3-week randomized crossover study. European Journal of Clinical Nutrition. 72(2), 249-254. https:// doi.org/10.1038/s41430-0170042-5

Froyen, -E., Burns-Whitmore, -B., 2020. The effects of linoleic acid consumption on lipid risk markers for cardiovascular disease in healthy individuals: A review of human intervention trials. Nutrients. 12(8), 1-19. https://doi.org/10.3390/nu12082329

Grajeda-Iglesias, -C., Aviram, -M. 2018. Specific amino acids affect cardiovascular diseases and atherogenesis via protection against macrophage foam cell formation: Review article. Rambam Maimonides Medical Journal. 9(3), 1-11. https://doi.org/10.5041/rmmj.10337 
Kanetro, -B., Setyowati, -A., 2013. Profil asam amino penstimulasi sekresi insulin dalam ekstrak sesudah pemisahan protein kecambah kacangkacangan lokal. Agritech. 33(3), 258-264.

Kim, -H., Caulfield, L, -E., Garcia-Larsen, V., Steffen, L, -M., Coresh, -J., Rebholz, C, -M., 2019. Plant-Based diets are associated with a lower risk of incident cardiovascular disease, cardiovascular disease mortality, and all-cause mortality in a general population of middle-aged adults. Journal of the American Heart Association. 8(16). https://doi.org/10.1161/JAHA.119.012 865

Kris-Etherton, $\quad$ P, $\quad$-M., 1999. Monounsaturated Fatty Acids and Risk of Cardiovascular Disease. AHA Journal. 24(100), 1253-1258. https://doi.org/10.1161/01.CIR.100.11. 1253

Le Douce, -J., Maugard, -M., Veran, -J., Matos, -M., Jégo, -P., Vigneron, P, -A., Faivre, -E., Toussay, $-\mathrm{X}$., Vandenberghe, -M., Balbastre, -Y., Piquet, -J., Guiot, -E., Tran, N, -T., Taverna, -M., Marinesco, S., Koyanagi, -A., Furuya, -S., GaudinGuérif, -M., Goutal, -S., ... Bonvento, G., 2020. Impairment of glycolysis-derived L-Serine production in astrocytes contributes to cognitive deficits in alzheimer's disease. Cell Metabolism. 31(3), 503-517. https://doi.org/10.1016/j.cmet.2020.02. 004

Lintschinger, -J., Fuchs, -N., Moser, -H., Jäger, -R., Hlebeina, -T., Markolin, -G., Gössler, -W., 1997. Uptake of various trace elements during germination of wheat, buckwheat and quinoa. Plant Foods for Human Nutrition. 50(3), 223237.

https://doi.org/10.1007/BF02436059

Ma, H., Shieh, K, J., 2006. Cholesterol and human health. The Journal of American Science. 2(1), 46-50.

Ma, L, L., Ji, G, Y., Jiang, Z, Q., 2014. Influence of dietary amino acid profile on serum lipids in hypercholesterolemic Chinese adults. Journal of Nutrition \& Food Sciences. 4(1), 1-6. https://doi.org/10.4172/2155-
9600.1000258

Maharani, -A., Sujarwoto, Praveen, -D., Oceandy, -D., Tampubolon, -G., Patel, A., 2019. Cardiovascular disease risk factor prevalence and estimated 10-year cardiovascular risk scores in Indonesia: The SMARThealth Extend study. PLOS ONE. 14(4), 1-13. https://doi.org/10.1371/journal.pone.0 215219

Marton, -M., Mandoki, -Z., Csapo, -J., 2010. Evaluation of biological value of sprouts I . Fat content, fatty acid composition. The Journal of Sapientia Hungarian University of Transylvania. 3, 53-65.

Mensink, R, -P., Janssen, M, -C., Katan, M, B., 1988. Effect on blood pressure of two diets differing in total fat but not in saturated and polyunsaturated fatty acids in healthy volunteers. American Journal of Clinical Nutrition. 47(6), 976980. https://doi.org/10.1093/ajcn/47.6.976

Minekus, -M., Alminger, -M., Alvito, -P., Ballance, -S., Bohn, -T., Bourlieu, -C., Carrière, -F., Boutrou, -R., Corredig, M., Dupont, -D., Dufour, -C., Egger, -L., Golding, -M., Karakaya, -S., Kirkhus, B., Le Feunteun, -S., Lesmes, -U., Maclerzanka, -A., MacKie, -A., ... Brodkorb, -A., 2014. A standardised static in vitro digestion method suitable for food-an international consensus. Food and Function. 5(6), 1113-1124. https://doi.org/10.1039/c3fo60702j

Naghshi, -S., Sadeghi, -O., Willett, W, -C., Esmaillzadeh, -A., 2020. Dietary intake of total, animal, and plant proteins and risk of all cause, cardiovascular, and cancer mortality: Systematic review and dose-response meta-analysis of prospective cohort studies. The BMJ. 370 . https://doi.org/10.1136/bmj.m2412

Nouran, M, G., Kimiagar, -M., Abadi, -A., Mirzazadeh, -M., Harrison, -G., 2010. Peanut consumption and cardiovascular risk. Public Health Nutrition. 13(10), 1581-1586. https://doi.org/10.1017/S1368980009992837

O'rielly, -R., Li, -H., Lim, S, -M., Yazbeck, -R., Kritas, -S., Ullrich, S, S., Feinle-Bisset, C., Heilbronn, -L., Page, A, -J., 2020. The effect of isoleucine supplementation on 
Jurnal Teknologi Pertanian Vol. 22 No. 3 [Desember 2021] 187-200

Potensi Minuman Fungsional Berbasis Susu dengan Isolat Biji dalam Pencegahan Penyakit Kardiovaskular [Kanetro dkk]

body weight gain and blood glucose response in lean and obese mice. Nutrients. $12(8)$, 1-12. https://doi.org/10.3390/nu12082446

Park, -T., Oh, -J., Lee, -K., 1999. Dietary taurine or glycine supplementation reduces plasma and liver cholesterol and triglyceride concentrations in rats fed a cholesterol-free diet. Nutrition Research. 19(12), 1777-1789. https://doi.org/10.1016/S02715317(99)00118-9

Puwastien, -P., Siong, T, -E., Kantasubrata, J., Craven, -G., Feliciano, R, -R., Judprasong, -K., 2011. Asean Manual of Nutrient Analysis. Institute of Nutrition, Mahidol University, Thailand

Ratnayake, W, M, -N., Hansen, S, -L., Kennedy, M, P., 2006. Evaluation of the CP-Sil 88 and SP-2560 GC columns used in the recently approved AOCS Official Method Ce 1h-05: Determination of c/s-, trans-, saturated, monounsaturated, and polyunsaturated fatty acids in vegetable or nonruminant animal oils and fats by. JAOCS, Journal of the American Oil Chemists' Society. 83(6), 475-488. https://doi.org/10.1007/s11746-0061230-y

Razak, M, -A., Begum, P, -S., Viswanath, -B., Rajagopal, -S., 2017. Multifarious Beneficial Effect of Nonessential Amino Acid, Glycine: A Review. Oxidative Medicine and Cellular Longevity. 2017, 1-8. https://doi.org/10.1155/2017/1716701

Singh, -M., Muralidhara Rao, -D., Pande, -S., Battu, -S., Mahalakshmi, -K., Rajeswar Dutt, -K., Ramesh, -M., 2011. Medicinal uses of L-Lysine: Past and future. International Journal of Research in Pharmaceutical Sciences, 2(4), 637-642.

Steinmetz, K, -A., Childs, M, -T., Stimson, C., Kushi, L, -H., McGovern, P, -G., Potter, J, -D., Yamanaka, W, -K., 1994. Effect of consumption of whole milk and skim milk on blood lipid profiles in healthy men. American Journal of Clinical Nutrition. 59(3), 612-618. https://doi.org/10.1093/ajen/59.3.612

Vasilopoulou, -D., Markey, -O., Kliem, K, E., Fagan, C, -C., Grandison, A, -S., Humphries, D, -J., Todd, -S., Jackson, K, -G., Givens, D, -I., Lovegrove, J, -A., 2020. Reformulation initiative for partial replacement of saturated with unsaturated fats in dairy foods attenuates the increase in LDL cholesterol and improves flowmediated dilatation compared with conventional dairy: The randomized, controlled REplacement of SaturatEd fat in dairy on Total cholesterol (RESET) study. American Journal of Clinical Nutrition. 111(4). 739-748. https://doi.org/10.1093/ajen/nqz344

Yildiz, F. 2006. Phytoestrogens In Functional Foods. Taylor \& Francis Group CRC Press. Florida, USA

Yoshiaraa, L., -Y., Mandarinob, J, M, -G., Carrão-Panizzic, M, -C., Madeiraa, T, B., Silvaa, J, -B., Camargoa, A, -C., Idaa, -D., Shahidid, -F., Iouko, -E., 2018. Germination changes the isoflavone profile and increases the antioxidant potential of soybean. Journal of Food Bioactives. 3, 144-150. https://doi.org/10.31665/JFB.2018.3157 